\title{
Editorial: Biogeochemical Responses of Tropical Ecosystems to Environmental Changes
}

\author{
Luiz Drude Lacerda ${ }^{1 * t}$, Stephane Mounier $^{2 \dagger}$ and Venugopalan Ittekkot ${ }^{3+}$ \\ ${ }^{1}$ Instituto de Ciências do Mar, Universidade Federal do Ceará, Fortaleza, Brazil, ${ }^{2}$ CNRS/INSU, IRD, MIO UM, Université de \\ Toulon, La Garde, France, ${ }^{3}$ University of Bremen, Bremen, Germany
}

Keywords: biogeochemistry, coastal ecosystems, tropical coasts, regional environmental changes, global warming

Editorial on the Research Topic

Biogeochemical Responses of Tropical Ecosystems to Environmental Changes

OPEN ACCESS

Edited by:

Gilad Antler,

Ben-Gurion University of the Negev,

Israel

Reviewed by:

Sambuddha Misra,

Indian Institute of Science (IISC), India

Yeala Shaked,

Hebrew University of Jerusalem, Israel

*Correspondence: Luiz Drude Lacerda Idrude@pq.cnpq.br

${ }^{\dagger}$ These authors have contributed equally to this work

Specialty section:

This article was submitted to

Biogeoscience,

a section of the journal

Frontiers in Earth Science

Received: 21 August 2020 Accepted: 14 September 2020

Published: 01 October 2020

Citation:

Lacerda LD, Mounier S and Ittekkot V

(2020) Editorial: Biogeochemical

Responses of Tropical Ecosystems to

Environmental Changes.

Front. Earth Sci. 8:597744.

doi: 10.3389/feart.2020.597744
Recent intensification of existing anthropogenic drivers and the emergence of new ones suggest the need for sustained efforts to understand their impacts on tropical and subtropical coastal ecosystems. Among them, mangroves, coral reefs, and seagrass beds are particularly ecologically important ecosystems, whose response to such impacts are still far from being understood. Also, most literature deals with the response of the biological component of these ecosystems to pressures from regional and/or global environmental changes. In our view, there is still a large gap regarding these ecosystems' geochemical and biogeochemical responses. Approaches taking into consideration the continuum between watersheds and the ocean and the processes involved in their continuity are particularly inadequate. In addition, long-term studies covering large geographical scales are scarce and are usually threatened by economic instability of many nations along the world's tropical coasts.

The described scenario calls for joint efforts to promote multidisciplinary research that encompass the mosaic of natural ecosystems distributed along tropical coasts worldwide and linking watershed processes and the oceanic receptor. They should aim toward a comprehensive view of major alterations in the fluxes, transformation and the cycle of substances at the continentocean interface, which promote environmental changes leading to pollution, eutrophication, oxygen minimum zones, and related biological crises.

Of significance are the studies concerning the fate of carbon, nutrients, and persistent pollutants; involving their biogeochemical cycles in estuaries, coastal waters and the continental shelf. Of interest are those that assess anthropogenic influence on the interaction between drainage basins and the continent-ocean interface, as well as the impacts on the continental shelf. The studies should aim at understanding of the implications of global changes to ecosystem functioning, conservation, and sustainable development; the vulnerability of the continent-ocean interface and threats to the society through food security and human occupation of the coastal zone, with emphasis on tropical coasts.

Considering the above scenario, the present paper collection includes five original research studies and one novel hypothesis dealing with the biogeochemical responses of tropical coastal ecosystems to impacts derived from regional and global environmental changes. Emphasis on tropical latitudes brings new insights on the response of these ecosystems of high global significance and expands the necessary knowledge-base of such phenomena to formulate and implement mitigation and adaptability policies and actions (Gedan et al., 2011).

Four of the six papers are dedicated to mangrove ecosystems, the dominant formation at the continent-sea interface along the tropics. Mangroves are on the frontline receiving environmental pressures from both land- and sea-based human activities, as well as from global warming. The latter 
acts upon the ecosystems through sea level change, alteration of rainfall regime and increasing storminess and frequency of extreme climate events. Impacts from such pressures tend to be more intense in extreme environments, such oceanic islands and semiarid coasts (Jennerjahn et al., 2017).

Mean winter air temperature increase has led to a poleward migration of mangroves at the limits of their geographical distribution and this expansion corresponds to the poleward extension of mild temperature zones in the past half century (Cavanaugh et al., 2014). Change in sea level is the best studied pressure on mangroves, since dated sediment cores extending from decades to millennia, provide insightful templates of the mangrove response to this pressure. Rising sea level, before it reaches a catastrophic stage, strongly affects hydrology, surface and groundwater salinity, and soil stability, creating new competitive requirements for natural animals and plants and thus affecting ecosystems functioning (Jennerjahn et al., 2017). The ubiquitous response is landward migration, which is the best documented response of mangroves to sea level rise. Although observed worldwide, it is consistently more intense along semiarid coasts, associated with lower annual rainfall and fluvial fluxes; see Godoy and Lacerda (2015) for a review. The biogeochemical consequences of expanding mangroves are not only in terms of vegetation changes. They also affect typical mangrove biogeochemical processes involving the regional cycles of sulfur, carbon, nutrients, and trace elements of the new colonized areas.

The consequences of environmental changes on mercury remobilization due to changes in mangrove expansion are the subject of the hypothesis proposed by Lacerda et al. (2020) in the present collection. The authors propose and describe response mechanisms involving the increasing complexation of mercury, a highly toxic and persistent metal pollutant, by dissolved organic carbon (DOC) compounds produced by mangroves. They also show significant changes in the chemical speciation of $\mathrm{Hg}$ in surface and pore waters, which reflect on the $\mathrm{Hg}$ dynamics in adjacent continental shelf waters. Increasing aridity and expansion of mangroves observed in many tropical regions are intensifying and expanding the biogeochemical realm of mangroves worldwide, resulting in increasing mercury bioavailability, the export of dissolved organo-Hg compounds to the continental shelf, contamination of the biota and human exposure to $\mathrm{Hg}$. The major result of such mechanisms, operating more intensely in tropical semiarid estuaries, is paradoxically similar to those described in the Arctic Ocean, confirming that extreme environments display stronger response to environmental changes.

The study by Dupouy et al. (2020) deals with the identification of the origin of DOC compounds in the coastal waters in and around the Eastern Lagoon of New Caledonia and examines its relationships to environmental forcing. Different biologicallyderived DOC in the water column of the lagoon showed that the humic-like components are particularly influenced by rainfall and terrigenous inputs, both variables that are strongly affected by global warming. Protein-like fluorophores, on the other hand, showed different dependencies on local wind and rain conditions. Spectrofluorimetry allowed the description of different processes involved in the transformation of DOC in tropical lagoons, which is also linked to metal mobilization, reducing or enhancing contamination.

Sanyal et al. (2020) present an original assessment of the dynamics of dissolved organic matter in the coastal environments dominated by the largest mangrove forest in the world, the Indian Sundarbans. Tidal transport from coastal wetlands ("outwelling"), in conjunction with riverine fluxes, provides most important sources of terrigenous dissolved organic matter to the ocean. Interannual, seasonal, and diurnal analysis along Sundarbans estuaries, covering pre-monsoon, monsoon, and post-monsoon periods, showed large variability of DOC concentrations and non-conservative mixing of DOC along the salinity gradient, strengthening the importance of the mangrove inputs, particularly in the polyhaline waters where DOC concentrations are higher. The observed higher DOC concentration during the post-monsoon associates with higher litter production and of DOC enrichment occurred in surface waters during the low tide, maximizing its outwelling. Overall, fluxes of organic matter resulted in higher yield and export of mangrove-derived DOC to the Bay of Bengal compared to riverine transport.

Most DOC exported by mangroves are also key components of trophic food chains along tropical coastlines. Therefore, factors affecting mangrove productivity reverberate in the functioning of coastal food webs, in particular leaf litter production and decomposition rates. Vinh et al. (2020) explore these aspects in coasts where these processes are strongly influenced by monsoons. Detailed analysis of nutrients, $\delta^{13} \mathrm{C}$ and trace metals of the litter decomposing process during the monsoon showed that leaf litter decay rates increased in white mangrove (Avicennia) stands, because of enhanced leaching from a higher level of rivers due to heavy rainfall. This resulted in strong ${ }^{13} \mathrm{C}$ depletion, but there was no clear trend of nutrient concentrations changes, which are dependent on the different element considered. However, enrichment in most trace metals was observed, which suggests that these metals were either trapped from the water column at the forest floor by organic molecules composing the litter. Once trapped, the metal-organic compounds can be incorporated by litter decomposers or other benthic feeing organisms. Their results show that the release or the uptake of elements during mangrove leaf litter decomposition varied with different parameters, which may have ecological implications on the nature of the elements exported to adjacent areas and on their primary productivity. This also corroborates further the importance of DOC on the biogeochemistry of tropical coastal areas.

A detailed analysis of the methanogenic activity and the microbial community structure in response to different mineralization pathways in paddy soils by Zhuang et al. (2020) increases the comprehension of the decomposition process. Tropical soils and sediments are characterized by the presence of iron oxides in a wide range of minerals, mostly poorly crystalline ferrihydrites. Depending on the geochemical conditions, microbial reduction of ferrihydrite leads to the formation of different secondary mineralization products including siderite, magnetite, vivianite, and green rust of 
specific contribution to biogeochemical cycles and processes in tropical coastal ecosystems. These products play an important role in the $\mathrm{C}$ and $\mathrm{S}$ cycles and, as commented above, on the mobilization of trace elements. Typically, microbial reduction of ferrihydrite has been considered in the study of microbial methanogenesis, highly overlooked as a significant mineralization process, compared for example, with sulfate reduction. The authors evaluate the methanogenic activity and the responsible microbial community structure of a paddy soil, in response to different mineralization pathways of ferrihydrite, which is transformed to magnetite or vivianite. Species of the Methanocelaceae and Methanosarcinaceae were the dominant methanogens in the studied soils, whereas syntrophic acetateoxidizing bacteria of the Clostridiaceae and syntrophic propionate-oxidizing bacteria of the Syntrophobacteraceae were highly enriched in magnetite cultures. The facilitated $\mathrm{CH}_{4}$ production observed in magnetite cultures might be related to the dynamic cycle of $\mathrm{Fe}(\mathrm{III})-\mathrm{Fe}(\mathrm{II})-\mathrm{Fe}(\mathrm{III})$ or magnetite-stimulated direct interspecies electron transfer between syntrophic acetate/propionate oxidizers and methanogens. Although further investigation is needed to upscale the observed results. These results contribute to the better understanding of the biogeochemical cycling of $\mathrm{Fe}, \mathrm{C}$, and $\mathrm{P}$ in anaerobic soils and sediments, fundamental for the interpretation of the impacts of environmental changes on the biogeochemistry of tropical coastal environments; although further investigation is needed to upscale the observed results.

Another widely distributed group of plants along tropical coast are seagrasses, which due to its benthic habitat experience considerable spatio-temporal changes in light and other biogeochemical conditions and adopt spices specific strategies to acclimatize. This already stressful condition put seagrasses amongst the mostly threatened marine plants following environmental changes. Ramachandran et al. (2020) studied the variation in photoacclimatory responses of three tropical seagrass species; the first time for seagrasses from the coastal waters of India. They found photosynthetic electron transport correlated with photosynthetic oxygen evolution in the studied species. The effective quantum yield, a good predictor of stress conditions in seagrass, correlates with the difference in water temperature and $p \mathrm{CO}_{2}$ for the three seagrass species. These results may support assessment studies by predicting the photo-acclimation strategies to any change in light availability, as well as subsequent biogeochemical changes at the surface of bottom sediments by these shallow water tropical seagrass species. These changes are already occurring due to global warming and alterations of land uses in watersheds around the world's tropical belt.

Based on the published results, there is a certain agreement and consistency of the response of tropical coastal ecosystems to global warming and regional changes that allows a certain degree of generalization. Inter-related and spatially variable pressures including sea level rise, increased storminess, altered precipitation regime, varying continental runoff and increasing temperature are impacting these ecosystems at regional scales (Ward et al., 2016); but the intensity of the response seems site-specific (Godoy and Lacerda, 2015) and species-specific (McKee and Rooth, 2008;
Ramachandran et al., 2020). Interactions with local anthropogenic drives, in particular damming, basin diversion, and eutrophication, also modify the intensity of the ecosystems' response, either favoring or hampering adaptability (Dupouy et al., 2020; Lacerda et al., 2020). The biogeochemistry of tropical coastal ecosystems is affected by the interaction between multiples stressors of local, regional, and global scales. On the other hand, estuarine and adjacent coastal areas are directly influenced by what occurs in these ecosystems, mostly related to changes in sedimentology and hydrology. Also of relevance are the drastic alterations in water, pore water, and sediment chemistry, in particular processes involved in the DOC dynamics. The majority of the reported changes ultimately favor the oxidation of reduced minerals (mostly sulfides) present in sediments This triggers the mobilization of accumulated nutrients and pollutants as well as increases methane and $\mathrm{CO}_{2}$ emission, as a result of the aerobic respiration of partially degraded sedimentary organic matter (Mounier et al., 2018; Zhuang et al., 2020). Sulfate reduction and methanogenesis seem competing mechanisms, but both are unable to fully degrade deposited organic matter and thus exports large quantities of dissolved organic complexes from the deposited sedimentary organic matter to waters, which increases metal mobilization through organic-complexation and bioavailability (Vinh et al., 2020) and more efficient and fast bioaccumulation rates and higher human exposure to pollutants (Lacerda et al., 2020).

The described biogeochemical events are extremely sensitive to global and regional environmental changes. The response of tropical coastal ecosystems, unfortunately already occurring worldwide, particularly along poorly studied tropical littorals, has been virtually neglected. Some questions need urgent attention: How remobilization or changes in bioavailability of nutrients and pollutants will occur within ecosystems already submitted and responding to various degrees of environmental pressure? Will these processes be significant relative to environmental health by triggering eutrophication and pollution? Are the existing results scalable to the world tropical belt? These gaps and questions regarding the biogeochemical impacts related to the tropical coastal ecosystems responses to global warming and regional environmental changes need urgent assessment, in order to achieve the necessary conservation and sustainable utilization of these ecosystems in the Anthropocene.

\section{AUTHOR CONTRIBUTIONS}

The three authors have equally contributed to this editorial.

\section{ACKNOWLEDGMENTS}

We thank Fundação Cearense de Apoio ao Desenvolvimento Científico e Tecnológico (FUNCAP), Conselho Nacional de Desenvolvimento Científico e Tecnológico (CNPq) the CAPES-COFECUB International Agreement between UFC (Brazil) and UTLN (France). 


\section{REFERENCES}

Cavanaugh, K. C., Kellner, J. R., Forde, A. J., Gruner, D. S., Parker, J. D., Rodriguez, W., et al. (2014). Poleward expansion of mangroves is a threshold response to decreased frequency of extreme cold events. Proc. Natl. Acad. Sci. U. S. A. 111, 723-727. doi:10.1073/pnas.1315800111

Dupouy, C., Röttgers, R., Tedetti, M., Frouin, R., Lantoine, F., Rodier, M., et al. (2020). Impact of contrasted weather conditions on CDOM absorption/ fluorescence and biogeochemistry in the eastern lagoon of New Caledonia. Front. Earth Sci. 8, 54. doi:10.3389/feart.2020.00054

Gedan, K. B., Kirwan, M. L., Wolanski, E., Barbier, E. B., and Silliman, B. R. (2011). The present and future role of coastal wetland vegetation in protecting shorelines: answering recent challenges to the paradigm. Clim. Change. 106, 7-29. doi:10.1007/s10584-010-0003-7

Godoy, M. D. P., and Lacerda, L. D. d. (2015). Mangroves response to climate change: a review of recent findings on mangrove extension and distribution. An. Acad. Bras. Ciênc. 87, 651-667. doi:10.1590/0001-3765201520150055

Jennerjahn, T. C., Gilman, E., Krauss, K. W., Lacerda, L. D., Nordhaus, I., and Wolanski, E. (2017). "Mangrove ecosystems under climate change," in Mangrove ecosystems: a global biogeographic perspective. Editors V. H. Rivera-Monroy, S. Y. Lee, E. Kristensen, and R. R. Twilley (Berlin, Germany: Springer), 211-244.

Lacerda, L. D. d., Marins, R. V., and Dias, F. J. d. S. (2020). An arctic paradox: response of fluvial $\mathrm{Hg}$ inputs and bioavailability to global climate change in an extreme coastal environment. Front. Earth Sci. 8, 93. doi:10.3389/feart.2020.00093

McKee, K. L., and Rooth, J. E. (2008). Where temperate meets tropical: multifactorial effects of elevated $\mathrm{CO}_{2}$, nitrogen enrichment, and competition on a mangrove-salt marsh community. Glob. Chang. Biol. 14, 1-14. doi:10.1111/j.1365-2486.2008.01547.x

Mounier, S. J., Lacerda, L. D., and Marins, R. V. (2018). "Determining the influence of urbanization on mangrove zones of northeastern Brazil," in Threats to mangrove forests. Editor C. Makowski (Berlin, Germany: Springer), 199-222.
Ramachandran, P., Ganguly, D., Hariharan, G., Arumugam, K., and Ramesh, R. (2020). In situ photosynthetic activities and associated biogeochemical changes in three tropical seagrass species. Front. Earth Sci. 8, 467540. doi:10.3389/feart. 2020.467548

Sanyal, P., Ray, R., Paul, M., Gupta, V. K., Acharya, A., Bakshi, S., et al. (2020). Assessing the dynamics of dissolved organic matter (DOM) in the coastal environments dominated by mangroves, Indian Sundarbans. Front. Earth Sci. 8. doi:10.3389/feart.2020.00218

Vinh, T. V., Allenbach, M., Linh, K. T. V., and Marchand, C. (2020). Changes in leaf litter quality during its decomposition in a tropical planted mangrove forest (Can Gio, Vietnam). Front. Environ. Sci. 8, 10. doi:10.3389/fenvs.2020. 00010

Ward, R. D., Friess, D. A., Day, R. H., and MacKenzie, R. A. (2016). Impacts of climate change on mangrove ecosystems: a region by region overview. Ecosyst. Health Sustain. 2 (4), e01211. doi:10.1002/ehs2.1211

Zhuang, L., Tang, Z., Yu, Z., Li, J., and Tang, J. (2020). Methanogenic activity and microbial community structure in response to different mineralization pathways of ferrihydrite in paddy soil. Front. Earth Sci. 7, 325. doi:10.3389/ feart.2019.00325

Conflict of Interest: The authors declare that the research was conducted in the absence of any commercial or financial relationships that could be construed as a potential conflict of interest.

Copyright (c) 2020 Lacerda, Mounier and Ittekkot. This is an open-access article distributed under the terms of theCreative Commons Attribution License (CC BY). The use, distribution or reproduction in other forums is permitted, provided the original author(s) and the copyright owner(s) are credited and that the original publication in this journal is cited, in accordance with accepted academic practice. No use, distribution or reproduction is permitted which does not comply with these terms. 